\title{
Features of soil renaturation: an application for ecological rehabilitation of disturbed lands
}

\section{Fedor Lisetskii}

Professor of Mining and Natural Resource Management, Belgorod State National Research University, Belgorod, Russian Federation Russia

\begin{abstract}
Land reclamation is disproportionate of areas that are diverted to mining, despite the requirements of environmental legislation. This creates an arena for the process of mine dumps overgrowth, which is similar to the renaturation abandoned sites. In a variety of the environmental conditions and with a wide amplitude of changes in factors, young ecosystems on the mine dumps and abandoned sites (after 30-70 years) form a spectrum of development pathways, which is characteristic of the adaptive self-organization of complex natural systems. Studying the various environmental restoration pathways of disturbed lands gives an understanding of the renaturation stages and rates, which allows moving to a controlled technology of plant and soil cover reproduction. The organic carbon accumulation values comparison in a comparable soil thickness showed that the efficiency of soil restoration in the forest-steppe with the postindustrial mine dumps renaturation compared to the restoration of the abandoned sites in the steppe zone were twice as high. This is due to the higher bioclimatic potential of the renaturation conditions; in particular, the sum of annual precipitation in the forest-steppe is more by $275 \mathrm{~mm}$ than in the steppe. However, the quantitative and qualitative indicators of pedogenesis (morphological structure, accumulation of organic carbon) show themselves similar to various bioclimatic conditions both in the renaturation of post technogenic and in the lands' ordinary mechanical disturbances, which would help to implement the universal technologies for the controlled renaturation of the disturbed lands. The established rates for the environmental rehabilitation of degraded land will be useful in implementing an irrecoverable conservation scenario where the most necessary types of ecosystems and aesthetic rehabilitation badlands can be formed.
\end{abstract}

KEY WORDS: MINE DUMPS, ABANDONED SITES, LAND RECLAMATION, ENVIRONMENTAL RECLAMATION, SOIL RESTORATION

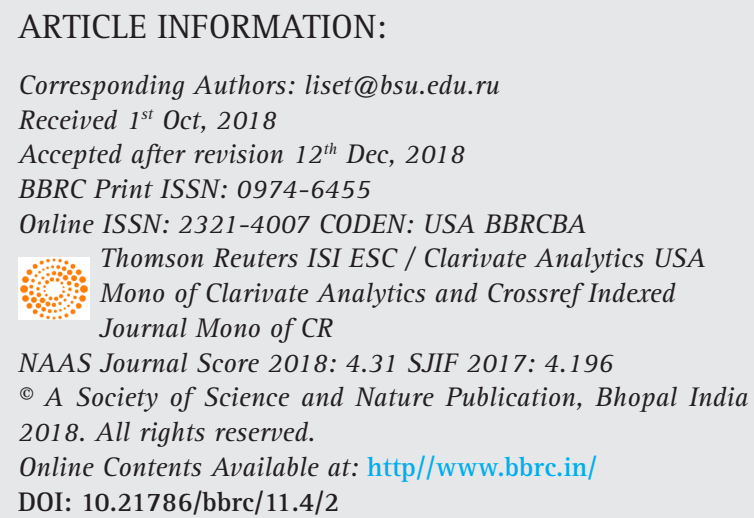




\section{INTRODUCTION}

The post-technogenic landscapes formation occurs under the combined influence of both natural and technological factors. The mining technology is connected with the formation of a technogenic relief, placement and rockto-earth ratio. Natural factors include the geographical location of the mine excavations area, their background landscape-ecological surroundings, habitats-sources availability and the age of technogenic complexes. Violated reclamation lands during the development of the mineral deposit and in connection with the industrial facilities construction, include the technical stage of the works. This stage creates a geomorphological and lithogenic basis for the formation of post-technogenic landscapes. At the same time, land survey work is usually carried out to smooth out the open pit sides, to create terraces on slopes at the mine dumps, planning recultivated surfaces for antierosion purposes, chemical reclamation (if necessary) of toxic rocks, or to apply a high-velocity layer from a potentially fertile rock. In the operation of ore mining and processing facilities, wastes are moved to tailing dumps, for which prevention activities or reduction of damage from environmental contamination are very important .The environmental reclamation of a mine dumps can be defined as the general process of repairing disturbed, damaged, degraded, or destroyed land with respect to its former or other productive uses, (Favas, 2017; Rafkatovich and Mironova, 2018).

The final part of the technical stage of reclamation moving the fertile soil layer out of the temporary mine dumps and applying it to the prepared surface - can be replaced with land renaturation, which was used, for example, in land reclamation for forestry use. Other methods of biological reclamation are now practiced plant growing (cultivation of agricultural crops); agromelioration (special methods of soil treatment); landscaping; agroforestry (protective forest belts); phytoreclamation (cultivation or maintenance of natural plant communities); bioremediation. The environmental reclamation is a broad concept encompassing all the other terms commonly referred to (restoration, rehabilitation, replacement, remediation, mitigation), used alone or combined (Gilland and McCarthy, 2014; Ngugi et al., 2015; Zenkov, 2016; Zamotaev et al., 2017; Favas, 2017).

Lands, where the methods of the biological reclamation are not involved and the process of mine dumps overgrowth is under way, can be under the controlled process of reproduction of plant and soil cover. The fact is that the rate of soil formations in overgrowth is small: only after 10 (12) years and more on the destroyed lands do the differentiation of plant species composition becomes dominant and a stable plant cover with layers and seasonal dynamics is formed (Golovanov et al.,
2009). If the surrounding ecosystems have a low regeneration potential, which is typical for internal areas of the technogenic landscapes, then the targeted construction of the ecosystem renaturation is the most rational way. The soil development depends on the hydrothermal and geochemical processes that cause differentiation of the landscape conditions both in the natural setting and on artificial structures (Lisetskii et al., 2016). Geochemical features of the technogenic substrates are determined by a more complex mineralogical composition (Alekseev et al., 2008) and high content of heavy metals (Akbari, 2016).

Formation of soil cover has a subordinate character with respect to the development of phytocenoses, although it proceeds syngenetically (Goleusov and Lisetskii, 2008). Technologies of renaturation should be based on observing the sequence of the main stages of succession of phytocenoses: pioneer groupings (1-3 years) simple groupings (3-8 years) - complex groupings (8-15 years). In the case of favourable edaphic and soil-forming properties of the substrate, accelerated renaturation scenarios are possible: the community's formation from "climax" plants species (Goleusov, 2003; Tokhtar and Martynova, 2015).

The bioclimatic potential study of the territory and the renaturation's natural mechanisms potential make it possible to outline effective optimal rehabilitation methods of disturbed lands. This study aims to assess the soil renaturation results of the destroyed lands during their formation by different types of anthropogenic transformation from the lithogenic basis under contrasting bioclimatic conditions.

\section{MATERIALS AND METHODS}

Study area: The study was carried out at two test sites: in the forest-steppe (Belgorod Oblast, career in the extraction of iron ore) and steppe (Crimean Peninsula, flat part). The area of Belgorod Oblast is relatively small (27.1 thousand $\mathrm{km}^{2}$ ), but over 200 kinds of useful minerals have been identified in this territory. The Kursk Magnetic Anomaly (KMA) is a large iron-ore province with a total area of 125 thousand $\mathrm{km}^{2}$ that extends from south-east to north-west at $625 \mathrm{~km}$ and a width of up to $250 \mathrm{~km}$ (Kornilov et al., 2014; Petin and Ignatenko, 2016). The territory of Belgorod Oblast includes 14 of 18 explored iron-ore mineral deposits of the KMA basin. The balance iron ore reserves in the Belgorod Oblast reach 51.32 bn $t$ (78\% of all KMA reserves or $51.2 \%$ of the reserves of Russia), and in addition the region contains $97.4 \%$ All-Russian stocks of rich ores (with Fe content 53-62\%) (Petin and Ignatenko, 2016).

In addition, Belgorod Oblast has 328 quarries of common minerals (chalk, clay, sand) on an area of about 1.5 thousand hectares. Among the study subjects in the 
KMA region, there are mine dumps of various types: excavating, car dumps, hydro dumps, where was not carried out reclamation by applying a fertile soil layer. The KMA region is located in the forest-steppe, where the climate is moderately continental with an average annual temperature of $5.4{ }^{\circ} \mathrm{C}$, and an annual precipitation of $616 \mathrm{~mm}$.

The objects of steppe region study were the abandoned settlements territories and earth mounds of World War II in the so-called belligerent landscapes. The steppe study area is located $700 \mathrm{~km}$ south-west of KMA and here the climate is very arid with mild winter, and the average annual temperature is higher by $4.6^{\circ} \mathrm{C}$ and an annual precipitation is less by $275 \mathrm{~mm}$.

Data used: The empirical basis of the study rests on the previously created databases in MS Access format, which contain author's pedochronological data (morphology, properties) in forest-steppe and steppe soils (numbers of security documents RU2010620190 and RU2016621001, respectively). The computer program, which is a database management system (DBMS) of the different-aged soils, allowed selecting data with comparable history. The objects of study in 2003-2016 were young differentaged soils (30-70 years old) and their parent rocks in the Belgorod region (KMA) and Steppe Crimea. If in the KMA forest-steppe area the study subjects are mining dumps that for 32-35 years have passed restoration, then in the steppe region, these landscapes age 68-73 years, which are formed on the destroyed lands as a result of the termination of human activity lands (abandoned sites, hills of ash, military trenches). Survey targets comparison in two regions reveals the role of bioclimatic conditions and the significant differences in the chemical composition of parent rocks.

Methods: The rate of humus horizon formation (accumulative (A) and transitional ( $\mathrm{AB})$ ) is taken as a relative indicator of soil formation effectiveness. The choice of an adequate mathematical model was based on the assumption that the model should reflect the rate of pedogenesis gradual deceleration, corresponding to the established organic matter equilibrium in the maximum concentration zone of soil biota in the renaturation horizon. Therefore, we chose the group of S-shaped growth models and in particular, a Gompertz function. Licensed software STATISTICA 10.0 was used for the modelling of the changes in the thickness of humus horizon (sum of $A$ and $A B$, if it is formed). Chemical analyses for soil horizons $\mathrm{A}$ and $\mathrm{AB}$ included the following standard procedures: the content of $\mathrm{CO}_{2}$ in carbonates measured by acidometry, bulk nitrogen content $(\mathrm{N})$ as determined by Kjeldahl's procedure, and $\mathrm{pH}_{\mathrm{H} 20}$.

The determination of Corg in the soil was performed by oxidation of the organic substance with a solution
$\mathrm{K}_{2} \mathrm{Cr}_{2} \mathrm{O}_{7}$ in sulfuric acid until the formation of carbon dioxide. The quality of the organic substance can be estimated based on the atomic ratio of C:N, which characterizes the degree of nitrogen enrichment of humus: if $\mathrm{C}: \mathrm{N}<5$, then very high, if $\mathrm{C}: \mathrm{N}<14$, then very low. Most of the humus horizons of the zonal-genetic row have a high and medium degree of enrichment of humus with nitrogen at C:N ratio of about 5-8 and 8-10, respectively. If using the index Corg for every $10 \mathrm{~mm}$ of soil thickness $(\mathrm{C} / 10 \mathrm{~mm})$, then the data is comparable in the analysis of individual objects. This is due to the fact that after the initial accumulation of soil organic matter in horizon A with the highest concentration of roots, the humus is moved down the profile as the pedogenesis time increases. Concentration of 22 macroelements and trace elements within the soils were determined by technique of measuring metals mass fraction and oxides in powder samples using the method of X-ray fluorescence analysis on the spectrometer (Spectroscan Max-GV). With weathering of iron-containing minerals, amorphous iron compounds are formed, which were extracted by Tamm's reagent (oxalate buffer solution $\left(\mathrm{H}_{2} \mathrm{C}_{2} \mathrm{O}_{4}{ }^{*} 2 \mathrm{H}_{2} \mathrm{O}+\left(\mathrm{NH}_{4}\right)_{2} \mathrm{C}_{2} \mathrm{O}_{4}{ }^{*} \mathrm{H}_{2} \mathrm{O}\right)$ with $\left.\mathrm{pH}=3\right)$. Soil colours (dry and moist) were described using the Munsell color system (Munsell, 1994).

\section{RESULTS AND DISCUSSION}

\section{Renaturation of the soil-plant cover}

Land reclamation involves the application of a fertile soil layer on a post-technogenic surface. However, when applying the layer of minimum thickness $(15 \mathrm{~cm})$, the payback period (upon the return of the used land to arable land) with the increasing delivery distance using scrapers from 300 to $1000 \mathrm{~m}$ will increase from 3 to 7 years. The land reclamation in the KMA is not carried out in due scope due to the lack of financial resources and insufficient technical equipment of mining companies. The annual increase in the area of destroyed land is comparable to the area of land, where reclamation was carried out. Therefore, Belgorod Oblast needs more than 100 years to fully reclamation of all disturbed lands, if the same reclamation rates continue in the future. The reclamation biological stage economic costs during formation of the post-technogenic landscape can be significantly reduced by controlling the restoration process.

Therefore, it is necessary to use the results of empirical studies that will allow selecting the most effective restoration trajectories and self-sustaining native ecosystem restoration. The soil-plant cover renaturation is a complex ensemble of natural reproduction processes of the biotic and abiotic geosystems components and the anthropogenic geosystem natural evolution, in which 
the economic activity was completed. A characteristic feature of technogenic geosystems is the high heterogeneity of their lithological base made of rocks that were moved in mine dump using the dry method or in the slurry form in the hydraulic filling process. And it is important to point out that these rocks belong to different geological formations and are often not parent rock for soil cover of the background landscapes.

In polycomponent technogenic mixtures, their environmental favourableness for renaturation is determined by the rocks ratio and, as a result of their mixing; the emergent properties of technogenic substrates appear. The morphology of the newly formed soil profiles of the technogenic landscapes strongly depends on the parent rock type. The soil profile is best formed in loamy and sandy-loamy rocks, soils on sands, clays, chalk and dense crystalline rocks are less developed. The biogeochemical cycle plays a determining role in the soil reproduction, including the process of complexes with organic residues, their transformation, mineralization, and humification (Lisetskii, 2012). Loamy soils better fix the organic matter.

With renaturation, aggregation processes are underway and the structure provides optimal water-air and microbiological regimes and favourable conditions for nutrient entry into the plants, improves anti-erosive soil stability in difficult terrain conditions (Bulygin and Lisetskiy, 1992). Biocenoses regeneration in ecotopes with a favourable substrate for the settlement of higher plants occurs at an accelerated rate, which determines the most active transformation of the mineral part within the rhizosphere area, where maximum organic matter accumulation is observed. Therefore, the maximum humus horizon formation rate (1.5-2 $\mathrm{mm} \mathrm{yr}^{-1}$ ) was noted with a soil aged of about 30 years.

\section{Soil restoration on the mine dumps}

In the forest-steppe, the results of renaturation postindustrial mine dump after 32-35 years (Table 1) are characterized by the following indicators of pedogenesis: the thickness of humus horizon is $43.3 \pm 2.9 \mathrm{~mm}$, the content of humus reaches $3.42 \pm 0.29 \%, \mathrm{~N}=0.26 \pm 0.02 \%$. These fertility indicators are formed under conditions when the content of $\mathrm{Fe}$ is $1.50 \pm 0.30 \%$, the soil solutions have a medium alkaline reaction $\left(\mathrm{pH}_{\mathrm{H} 20}=8.24 \pm 0.07\right)$, which is due to the carbonate content $\left(\mathrm{CO}_{2}=3.69 \pm 0.73 \%\right)$.

With renaturation postindustrial mine dumps, the processes of humus horizon formation and humus synchronously accumulates in the first three-four decades as a whole. Soils reproduction in technogenic landscapes under conditions of mine dumps overgrowth with overburden rocks occurs under rather extreme conditions; however, in most cases by the age of 30-40 years' young soils have a well-defined morphological profile.

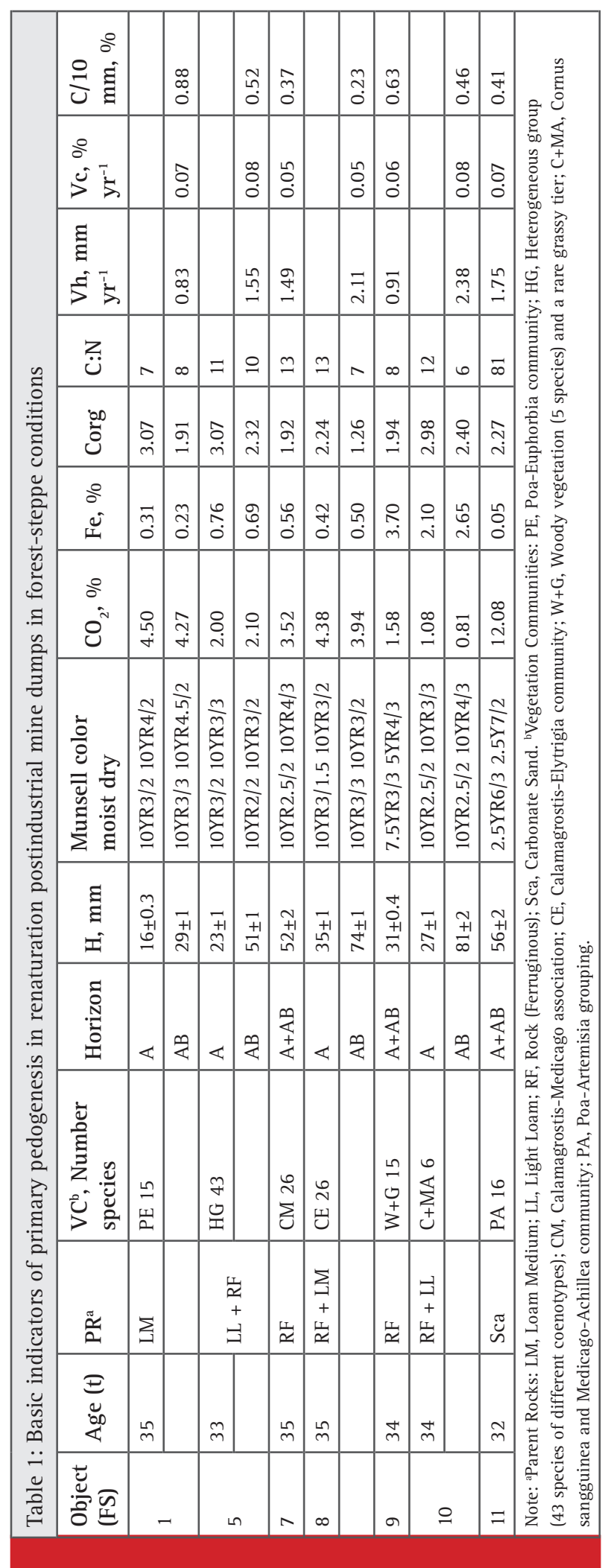

544 FEATURES OF SOIL RENATURATION: AN APPLICATION FOR ECOLOGICAL REHABLITTATION OF DISTURBED LANDS 
The greatest development among soil genetic horizons is obtained by humus - accumulative (A) and transitional ( $\mathrm{AB}$ or $\mathrm{AC}$ (in the early stages)) horizons. The dependence of the total thickness $(A+A B(A C))$ of humus horizon $(\mathrm{H}(\mathrm{t}), \mathrm{mm})$ on the time (t, years) in the early stage of pedogenesis in the technogenic landscapes of the forest-steppe has the form: $\mathrm{H}(\mathrm{t})=200 \exp (-\exp$ (0.923-0.025 t)). Using this model, it was found that the average rate of humus horizon formation of Chernozem-like soils (Vh) in the first 35 years is $2.00 \mathrm{~mm}$ $\mathrm{yr}^{-1}$.However, in the various substrates and phytocenotic conditions of the technogenic landscapes, significant differences in $\mathrm{Vh}(\mathrm{n}=22)$ from 0.83 to $2.38 \mathrm{~mm} \mathrm{yr}^{-1}$ are noted with a coefficient of 36\% variation. During this same time, the average rate of Corg accumulation is $1.86 \pm 0.15 \%$ with a coefficient of $38 \%$ variation. As shown in Table 1, with the exception of soil on sands, all other soils when achieving an average content of Corg = 2.2\% acquire a characteristic soil colour (dry) dark grayish brown (10YR4/2).

The maximum growth rates of the humus horizon thickness were noted, when rocks (Ferruginous) were mixed with loams, although the plant cover features were not a factor of pedogenesis rate differentiation. Nevertheless, the presence of woody vegetation (such as Cornus sangguinea) stimulated both soil growth downwards and Corg accumulation with a high degree of humus enrichment with nitrogen. As shown earlier (Goleusov, 2003), in the forest-steppe conditions, there are no significant differences in the pedogenesis efficiency under grass and tree vegetation in the early stages of renaturation, but at a later stage, the organic carbon accumulation rate in grassy communities becomes higher.

High Corg accumulation rates do not depend on the content of carbonates in parent rock and they are not hindered by the increased content amorphous $\mathrm{Fe}$ in the rocks of mining dumps. The lowest rates of Corg accumulation were noted on ferruginous rock and more favourable parent rocks (loam and loamy sand) were a more significant factor pedogenesis, than the diversity of plant species and type of vegetation. The high degree of humus enrichment with nitrogen ( $\mathrm{C}: \mathrm{N}=5-8)$ is always accompanied by high rates of humus horizon (Vh), but the ratio $\mathrm{C}: \mathrm{N}=8$ was also noted in cases where the maximum values of $\mathrm{C} / 10 \mathrm{~mm}$ were recorded.

At the quartzite mine dumps (KMA), vegetation in the early stages of recovery is very poor, but at the foot of the slopes where the meadow-steppe vegetation with ruderal species concentration, 58 species of plants are noted (Kornilov et al., 2008). At the age of young geosystems from 35 to 50 years and beyond, there comes a stage of sustainable geosystems operation where the structure and regeneration processes stabilize. The rate of soil reproduction decreases; the species composition in a phytocenosis gradually stabilizes; the share of ruderal species decreases.

\section{Soil restoration on the abandoned sites}

With mechanical destructions of land and the human activity termination, semi-natural landscapes (post-settlement, fortification, etc.) were formed with a variety of conditions on lithology and vegetation composition. In such conditions (Table 2), with an arid steppe climate, the average rate of humus horizon formation (Vh) for the first 70 years ranged from 1.1 to $2.3 \mathrm{~mm} \mathrm{yr}^{-1}$ with a variation coefficient of $28 \%$. During the same time, the average rate of Corg accumulation was $0.04 \% \mathrm{yr}^{-1}$ with a variation coefficient of $23 \%$, i.e. is identical to the accumulation of carbon on mine dumps KMA. In this way, judging by the values of the indicator $\mathrm{C} / 10 \mathrm{~mm}$, the pedogenesis efficiency (with respect to the accumulation of organic substance in a comparable thickness) during renaturation of the postindustrial mine dumps $(0.50 \%$ on $10 \mathrm{~mm}$ ) compared with the usual mechanical violations of land in the steppe zone was twice as high.This is due to the higher bioclimatic potential of renaturation conditions, which was typical for mining facilities of KMA in the forest-steppe. Consequently, we can note the higher species diversity and vegetation productivity during the overgrowth of mine dumps, despite the lesser age of ecosystems restoration in the forest-steppe compared with the steppe. In comparison with the young forest-steppe soil, colour is lighter in the steppe soils, which is mainly determined by the presence of such parent rock as ash.

Table 2 includes only the nine macroelements and trace elements that belong to the group "plant nutrients", and among them there are those that showed a significant variation (V>20\%) among the subjects studied. A comparison of the soil quality values that were obtained by calculating the geometric means for nine indicators (Table 2) showed that the richest soil (in biogeochemical terms) was formed in seven decades under conditions, when the parent rock was ash, although the plant cover was not characterized by maturity and diversity. Scenarios of ecological renaturation pathways are more diverse under overgrowth conditions of the postindustrial mine dumps in comparison with the restoration of the abandoned sites (settlements and fortification objects). It can be assumed that this is facilitated by more favourable climatic conditions of the forest steppe in comparison with the steppe. Moreover, the narrower scope of implemented pathways of renaturation of steppe ecosystems is due to the greater influence of adjacent ecosystems due to their territorial proximity. The important role of habitats-sources for the successions acceleration was shown in the definition of the kurgans vital role in steppe restoration (Deák et al., 2016). In areas where the 


\begin{tabular}{|c|c|c|c|c|c|c|c|c|c|}
\hline \multicolumn{2}{|l|}{ Object } & $\mathrm{S} 1 / 1$ & $\mathrm{~S} 1 / 2$ & S2 & S3 & S4 & S5 & S6 & Average \\
\hline \multicolumn{2}{|l|}{$\mathrm{PR}^{\mathrm{a}}$} & $\mathrm{A}$ & A & $\mathrm{T}$ & $\mathrm{T}$ & $\mathrm{T}$ & $\mathrm{BL}$ & A & - \\
\hline \multicolumn{2}{|l|}{$\mathrm{V}^{\mathrm{b}}$} & C & C & HG & GMG & MG & W & $\mathrm{W}$ & - \\
\hline $\mathrm{T}$ & yrs & 70 & 70 & 70 & 68 & 68 & 73 & 73 & - \\
\hline Horizon, depth & $\mathrm{mm}$ & A, 0-162 & $\mathrm{AB}, 162-280$ & A, 0-95 & A, $0-93$ & A, $0-122$ & A, $0-81$ & A, $0-98$ & - \\
\hline Munsell color & dry & 10YR 6/2 & 10YR 6/2 & 10YR 7/3.5 & 10YR 5/3 & 10YR $7 / 3$ & 10YR 6/3.5 & 10YR 5/2.5 & - \\
\hline Corg & $\%$ & 3.29 & 2.59 & 3.46 & 2.66 & 2.16 & 1.98 & 2.43 & 2.65 \\
\hline $\mathrm{P}_{2} \mathrm{O}_{5}$ & $\%$ & 1.33 & 1.39 & 0.28 & 0.15 & 0.21 & 0.30 & 0.49 & 0.59 \\
\hline $\mathrm{K}_{2} \mathrm{O}$ & $\%$ & 3.00 & 3.32 & 1.84 & 1.90 & 1.23 & 1.10 & 1.83 & 2.03 \\
\hline $\mathrm{Fe}$ & $\%$ & 2.15 & 2.08 & 2.00 & 3.10 & 1.62 & 1.47 & 1.92 & 2.05 \\
\hline $\mathrm{SiO}_{2}$ & $\%$ & 45.8 & 44.6 & 37.7 & 46.3 & 20.0 & 21.6 & 34.0 & 35.71 \\
\hline $\mathrm{CaO}$ & $\%$ & 16.9 & 17.7 & 21.8 & 6.5 & 36.0 & 28.1 & 16.5 & 20.51 \\
\hline Mg0 & $\%$ & 2.5 & 2.5 & 2.3 & 1.3 & 3.3 & 2.8 & 1.9 & 2.38 \\
\hline $\mathrm{Cu}$ & ppm & 20.8 & 21.4 & 24.7 & 43.1 & 35.0 & 38.9 & 42.1 & 32.29 \\
\hline $\mathrm{Zn}$ & ppm & 143.8 & 123.6 & 72.0 & 81.6 & 67.9 & 59.6 & 78.1 & 89.51 \\
\hline $\mathrm{Vh}$ & $\mathrm{mm} \mathrm{yr}^{-1}$ & - & 2.31 & 1.36 & 1.37 & 1.79 & 1.11 & 1.34 & 1.55 \\
\hline Vc & $\% \mathrm{yr}^{-1}$ & 0.05 & 0.05 & 0.05 & 0.04 & 0.03 & 0.03 & 0.03 & 0.04 \\
\hline $\mathrm{C} / 10 \mathrm{~mm}$ & $\%$ & - & 0.20 & 0.36 & 0.29 & 0.18 & 0.24 & 0.25 & 0.25 \\
\hline
\end{tabular}

ratio of natural habitats is high, we can expect a fast recovery of semi-natural habitats (Valkó et al., 2017).

\section{CONCLUSION}

The type and geochemistry of parent rock are the determining factors of pedogenesis and makes the main contribution to the soil properties variation that is close in age. Young ecosystems, that were formed in a variety of conditions (relief, lithology, climate, vegetation), through the environmental factor amplitude of oscillations could, in the self-organization process, enter one, but a development pathways spectrum, since they had many degrees of freedom. The range of the environmental renaturation efficiency in the forest-steppe under the recent pedogenesis conditions in postindustrial mine dumps is diagnosed to the greatest extent by the Corg/10 mm index and Vh is inferior to it. The small differences (with varying types of rocks and vegetation) are typical for the average rate of Corg accumulation. In the steppe zone, the range of values is less than in the forest-steppe and the manifestations of the processes that are reflected in indicators $\mathrm{C} / 10 \mathrm{~mm}$ and $\mathrm{Vh}$ and the average rate of Corg accumulation is inferior to them. Thereby, in various bioclimatic conditions, indicators of the pedogenesis efficiency on renaturation posttechnogenic and of conventional mechanical disorder lands manifest themselves in a similar way. This allows using the comprehensive technology of controlled renaturation of the disturbed lands. We attribute this type of renaturation to irrecoverable conservation, whose goal is to form the most "scarce" ecosystems with the selection of tolerant species, the creation of natural reserves and the badlands aesthetic rehabilitation. It is necessary to provide system solutions, since environmental renaturation in post mining sites includes stabilization of the relief, primary and recent pedogenesis, self-purification of natural environments (restoration of the geochemical balance), primary and regenerative biota successions (revitalization of anthropogenic surfaces), intercomponent geosystem interactions restoration.

\section{ACKNOWLEDGEMENTS}

The work was done in the framework of the implementation of the base part of the state assignment of the Ministry of Education and Science of the Russian Federation for the Belgorod State National Research University on 2017-2019 years (project No. 5.4711.2017/6.7).

\section{REFERENCES}

Akbari, Fereshteh Ali. (2016). The assessment of heavy metal contamination of landfill soil of Meshgin city using index of geoaccumulation and contamination factor. Bioscience Biotechnology Research Communications, 9(2): 308-312. 
Alekseev, A.O., Alekseeva, T.V., Hajnos, M., Sokolowska, Z., Kalinin, P.I. and Borisov, A.V. (2008). Modifications of the mineralogical composition and surface properties of soils as related to steppe climate dynamics in historical time. Eurasian Soil Sci., 41(13): 1424-1432.

Bulygin, S.Y. and Lisetskiy, F.N. (1992). Soil microaggregation as an index of erosion resistance. Eurasian Soil Sci., 24(3): 59-65.

Deák, B., Tóthmérész, B., Valkó, 0., Sudnik-Wójcikowska, B., Moysiyenko, I.I., Bragina, T.M., Apostolova, I., Dembicz, I., Bykov, N.I. and Török, P. (2016). Cultural monuments and nature conservation: a review of the role of kurgans in the conservation and restoration of steppe vegetation. Biodiversity and Conservation, 25(12): 2473-2490.

Favas, P.J.C. (2017). A reclamation procedure scheme of abandoned mine sites: A conceptual model. International Multidisciplinary Scientific GeoConference Surveying Geology and Mining Ecology Management, SGEM, 17(51): 9-14.

Gilland, K.E. and McCarthy, B.C. (2014). Microtopography influences early successional plant communities on experimental coal surface mine land reclamation. Restoration Ecology, 22(2): 232-239.

Goleusov, P.V. (2003). Soil formation under different combinations of substrate and phytocenotic conditions in the foreststeppe zone. Eurasian Soil Sci., 36(9): 937-945.

Goleusov, P.V. and Lisetskii, F.N. (2008). Soil development in anthropogenically disturbed forest-steppe landscapes. Eurasian Soil Sci., 41(13):1480-1486.

Golovanov, A.I., Zimin, F.M. and Smetanin, V.I. (2009). The reclamation of disturbed lands. (Ed) A. I. Golovanov, KolosS, Moscow. ISBN: 978-5-9532-0689-1

Kornilov, A.G., Petin, A.N. and Drozdova, E.A. (2014). Geomorphological and ecological-and-economic aspects of reclamation of mine dumps in the Kursk Magnetic Anomaly. Gornyi Zhurnal, 8: 74-78.

Kornilov, A.G., Petin, A.N., Kichigin, E.V., Prisniy, Yu.A., Kolchanov, A.F and Prisniy, A.V. (2008). Modern changes of natural components in Starooskol-Gubkin industrial region of Belgorod Oblast. Izvestiya Akademii Nauk, Seriya Geograficheskaya, 2: 85-92.

Lisetskii, F.N. (2012). Soil reproduction in steppe ecosystems of different ages. Contemporary Problems of Ecology, 5(6): 580-588.

Lisetskii, F.N., Sudnik-Wojcikowska, B. and Moysiyenko I.I. (2016). Flora differentiation among local ecotopes in the transzonal study of forest-steppe and steppe mounds. Biology Bulletin, 43(2): 169-176.

Munsell, A. (1994). Munsell Soil Color Charts. Revised Edition. Gretag Macbeth New Windsor, New York.

Ngugi, M.R., Neldner, V.J., Doley, D., Kusy, B., Moore, D. and Richter, C. (2015). Soil moisture dynamics and restoration of self-sustaining native vegetation ecosystem on an open-cut coal mine. Restoration Ecology, 23(5): 615-624.

Petin, A.N. and Ignatenko, I.M. (2016). Mineral-raw material resources of rich iron ores of the Belgorod district of the Kursk Magnetic Anomaly. Nauch. Ved. Belgorod. Gos. Univ., Ser. Estestv. Nauki, 37(25): 138-142.

Rafkatovich, A.K. and Mironova, K.V. (2018). Methods for the reduction of loss and optimization processes open pit mining operations when mining man-made deposits formed by sections. J. Eng. Appl. Sci., 13(7): 1624-1631.

Tokhtar, V.K. and Martynova, N.A. (2015). Selection of cultures for phyto-rehabilitation of mine dumps in the Kursk magnetic anomaly. Gornyi Zhurnal, 8: 96-99.

Valkó, O., Deák, B., Török, P., Kelemen, A., Miglécz, T. and Tóthmérész, B. (2017). Filling up the gaps - Passive restoration does work on linear landscape scars. Ecol. Engin., 102: 501-508.

Zamotaev, I.V., Ivanov, I.V., Mikheev, P.V. and Belobrov, V.P. (2017). Transformation and contamination of soils in iron ore mining areas (a review). Eurasian Soil Sci., 50(3): 359-372.

Zenkov, I.V. (2016). Review of foreign researches in the field of mining ecology. Gornyi Zhurnal, 10: 96-99. 